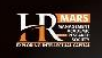 INTERNATIONAL JOURNAL OF ACADEMIC \\ HUMAN RESOURCE
MEAAGEENT CADAEMIC
RESEARCH SOCIETY

\section{Benefits and Risks of Online Shopping with Consumer's Perspective: A Case Study of Pakistan}

\author{
Usama Anwar, Abdul Rehman Nawaz, Ateeq Ullah, Shafique Ahmad
}

To Link this Article: http://dx.doi.org/10.6007/IJARAFMS/v11-i1/9691

DOI:10.6007/IJARAFMS /v11-i1/9691

Received: 21 January 2021, Revised: 18 February 2021, Accepted: 04 March 2021

Published Online: 25 March 2021

In-Text Citation: (Anwar et al., 2021)

To Cite this Article: Anwar, U., Nawaz, A. R., Ullah, A., \& Ahmad, S. (2021). Benefits and Risks of Online Shopping with Consumer's Perspective: A Case Study of Pakistan. International Journal of Academic Research in Accounting Finance and Management Sciences, 11(1), 499-511.

Copyright: (c) 2021 The Author(s)

Published by Human Resource Management Academic Research Society (www.hrmars.com)

This article is published under the Creative Commons Attribution (CC BY 4.0) license. Anyone may reproduce, distribute, translate and create derivative works of this article (for both commercial and non-commercial purposes), subject to full attribution to the original publication and authors. The full terms of this license may be seen at: http://creativecommons.org/licences/by/4.0/legalcode

Vol. 11, No. 1, 2021, Pg. 499 - 511

Full Terms \& Conditions of access and use can be found at http://hrmars.com/index.php/pages/detail/publication-ethics 


\title{
Benefits and Risks of Online Shopping with Consumer's Perspective: A Case Study of Pakistan
}

\author{
Usama Anwar ${ }^{1}$, Abdul Rehman Nawaz ${ }^{2}$, Ateeq Ullah³ ${ }^{3}$ Shafique \\ Ahmad $^{4}$
}

${ }^{1}$ School of Economics. Faculty of Business, Economics and Administrative Sciences. University of the Punjab, Lahore, Pakistan, ${ }^{2}$ School of Economics. Faculty of Business, Economics and Administrative Sciences. University of the Punjab, Lahore, Pakistan, ${ }^{3}$ Pakistan Institute of Development Economics

(PIDE), Islamabad, ${ }^{4}$ School of Economics. Faculty of Business, Economics and Administrative Sciences. University of the Punjab, Lahore, Pakistan.

Email: usama.anwar309@gmail.com

\begin{abstract}
The over-usage of the internet in Pakistan provides a developing prospect regarding online shopping. With the emerging technology and rapid growth in E-markets, it has become necessary to visualize consumer behavior and the factors that influence consumer behavior in online shopping system. The following paper uses the perceived benefits and risks as a measure to study consumer behavior in online shopping. A survey is conducted from students in Punjab province through google forms. A total of 150 responses were collected through convenience sampling and analyzed using SPSS-25 and Pearson correlation method. The findings show that shopping convenience, product selection, and ease of buying positively affect the buying behavior, whilst financial risk, product risk, and security risk are observed to have negative affect on online shopping behavior. However, none of these relations is found to be strong. The study concludes that consumers perceive certain benefits and risks in online shopping.
\end{abstract}

Keywords: Benefits, Consumer Behavior, Convenience, E-Commerce Online Shopping, Risks

\section{Introduction}

The Internet has become an emerging technology for the past few decades, and the number of internet users is growing day by day. The versatility of the internet has made an amazing attraction for people around the globe. People use it for different purposes like communication, education and research, entertainment, and e-commerce. Online Shopping refers to the purchasing of goods by utilizing the internet. Consumers can select from a wide range of products available on a specific brand's website and can order these products without walking into stores. The ease associated with online shopping is increasing day-by-day due to the advancement in internet technology. For online shopping, internet can be used for many purposes like one can review the prices and quality of 
INTERNATIONAL JOURNAL OF ACADEMIC RESEARCH IN ACCOUNTING, FINANCE AND MANAGEMENT SCIENCES

Vol. 11, No. 1, 2021, E-ISSN: 2225-8329 @ 2021 HRMARS

products: able to read opinions of other buyers about the products: may order the customized design, and place the order at any time of the day. Many selling companies also give the option to choose between paying via credit cards and pay after the products are received by the consumer. Online shopping has allowed consumers to buy products quickly and at better prices (Koyuncu \& Bhattacharya, 2004; Kuhlmeier \& Knight, 2005).

This research aims to investigate the benefits and risks that consumers perceive in online shopping. The study is based on the respondents' perception concerning the benefit and risks that they face. The trend of shopping is changing throughout the world with more people adopting online shopping systems due to the facilitation and the rapid advancement of internet technology. This has allowed consumers to make online purchases while being in their homes, offices and even out of town or country. Retailers in advanced countries have developed their portals where customers can buy their desirable products while staying at home and also can make online payments. It has become easy for retailers to spread information about discount offers or new products. Consumers can also access information about their favorite brands with just one click. Many Asian countries including Pakistan have also adopted this innovative and effortless way of shopping.

Many factors are significant in understanding the buying behavior of consumers affected that can have positive and negative implications. Consumers may prefer online shopping due to convenience, time, discounted deals, and after-sale services. But at the same time, some consumers may argue over the negative factors like security, quality, and reliability that can affect the way they prefer to shop. It is find out that factors like price, identification, convenience, critical information, discount offers are the main components that affect the online buying behavior of students and professionals. (Dost et al. 2015). Figure 1 shows that people do online shopping because they find the following benefits (Delhagen (1997) cited by Khatibi, Haque, and Karim (2006)) .

Figure 1: Benefits of online shopping

Source: Delhagen (1997)

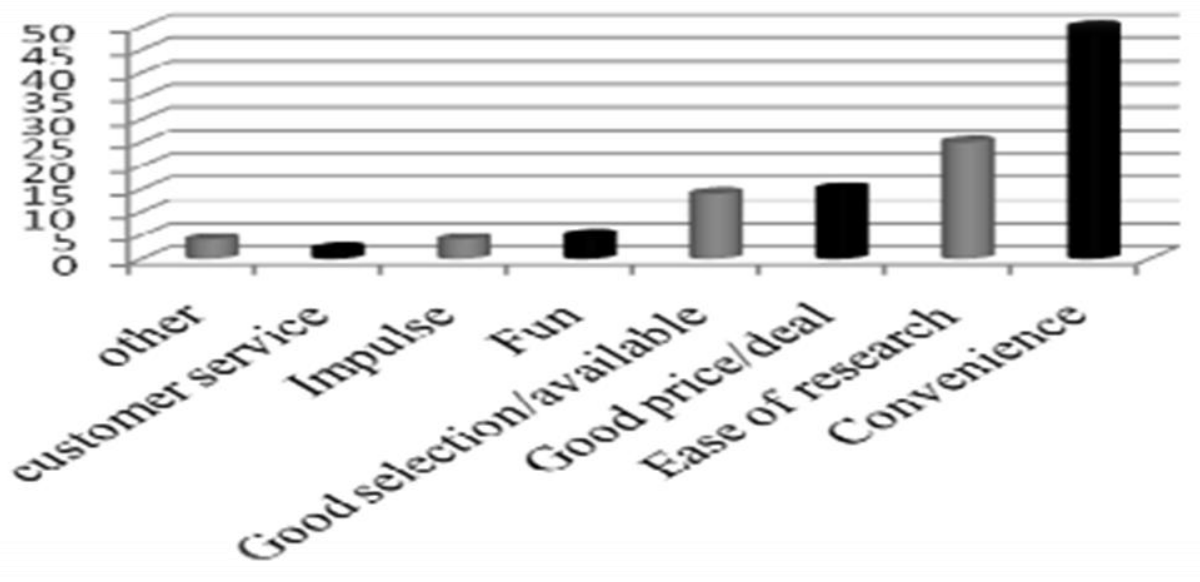

\section{Literature Review}

Information technology has made it possible for billions of people to access everything through the internet. The rapid and fast development in technologies also eased up the conduct of business. With the consumers changing behavior, more businesses are being shifted to online mode. The competition among retailers is growing day by day and they are trying to introduce new security techniques, quality, ease of buying, and a variety of products to attract customers. Researchers found 
INTERNATIONAL JOURNAL OF ACADEMIC RESEARCH IN ACCOUNTING, FINANCE AND MANAGEMENT SCIENCES

Vol. 11, No. 1, 2021, E-ISSN: 2225-8329 ๑ 2021 HRMARS

that ease of access, variety, and advertisements that encourage consumers to buy online are the encouraging factors: while many consumers think that the price fixation, quality, and the delivery time are the major discouraging factors in online shopping (Hussain et al. 2011). Hussain et al. (2011) also finds that the credit card payment system has enhanced the fashion of impulse buying.

Shopping Convenience. Convenience in every aspect of life is becoming a human priority in this age of technology and advancement. Customers are always curious to find new ways of attaining convenience. In this regard, Almarashdeh et al. (2019) collected surveys from 143 participants, and data were analyzed by using SPSS-25. He found that consumers feel more convenient in using mobile apps for online shopping as compared to websites for shopping. The author used the following variables in his convenience-based study: search convenience, access convenience, service recovery convenience, and behavioral intention to use. In addition to that, Beauchamp and Ponder (2010) show that people feel more convenient while online shopping and making transactions rather than in-store shopping. The data on four dimensions including assess, search, transaction, and possession, was collected through convenient sampling as well as from a national online panel. However, the author highlighted that people are less aware of the types of convenience that are available to them. Similarly, Jih (2007) discusses the relation between shopping convenience and online shopping intention. The primary data was collected from the students by convenience sampling method on the five dimensions that are place, acquisition, use, execution, and time. By using (ANOVA) canonical, correlation analysis, and regression analysis, it is figured out that convenience has a significant positive impact on shopping intention.

H1: Shopping convenience is positively related to consumer online buying behavior

Product Selection. Customers usually search for perfect quality products on the internet. Likewise, the brands that display a vast number of products with better quality are considered more successful. Guo surveys from 350 online shoppers to verify the impact of product variety and product quality on consumer satisfaction. He found that consumer satisfaction is positively related to product quality and product selection in online shopping. Previous researchers found different variables that encourage people to shop online, and product characteristics are one of them. Moreover, wider variety attracts consumer attention (Guo et al. 2012). Bin Dost et al. (2015) found that product variety has significant impact on consumer buying behavior. The author illustrated that youth buys more products online if they find more variety.

H2: Product selection is positively related to consumer online buying behavior

Ease/Comfort of Shopping. Researchers are always very eager to find the factors that compel people to shop online. Different people shop for different reasons. Their shopping reasons might be leisure, the pleasure of bargaining, physical activity, and outside experiences (Tauber 1995). Likewise, Ramayah and Ignatius (2005) developed the relation between intention to shop online and perceived enjoyment. He found that perceived enjoyment $(\beta=0.32, p<0.05)$ has not only a positive impact but also an important driver of consumer intention to shop.

By using Technology Acceptance Model author shows that consumer behavior is not affected by ease of use and usefulness but with the previous online shopping experience and trust. Comfort and ease of shopping usually depends upon trust. Everyone wants comfort in his life. Comfort makes people happy and enables them to work hard and be productive. Sometimes it makes people lazy. Similarly, 
INTERNATIONAL JOURNAL OF ACADEMIC RESEARCH IN ACCOUNTING, FINANCE AND MANAGEMENT SCIENCES

Vol. 11, No. 1, 2021, E-ISSN: 2225-8329 @ 2021 HRMARS

people want comfort in shopping not just in traditional one but also in E-shopping (Monsuwe et al. 2004).

Cheema measured the effect of perceived enjoyment on shopping intention by using the regression analysis. He surveyed 150 people that includes students and professionals. It is found that both ease of use and enjoyment have significant and positive impacts on consumer shopping intentions in Pakistan (Cheema et al. 2013). Akhter (2015) found internet usage comfort by using an ordinal regression model. He shows that internet usage brings comfort which has a significant positive impact on online shopping. Customers enjoy while searching for different products as they feel more comfortable in online shopping. It is no more difficult to try new experiences, products, and custom their designs in online shopping.

H3: Ease of buying is positively related to consumer online buying behavior

Financial Risk. There is a lot of debate going on about the negative aspects of online shopping and financial risk is one of them. Financial risk plays an important role in consumer decision making. This loss is termed as a net loss of money or money that might be lost. A negative impact of financial risk on consumer online shopping has been proved by previous literature. More often, people stop online shopping due to financial insecurities (Masoud \& Management 2013).

Similarly, Pi and Sangruang (2011) found the relationship between financial risk and internet shopping. By using the Least Square method he concluded that not just the financial risk but other risks like social, time, and convenience risks are also negatively related to online shopping.

H4: Financial risk is negatively related to consumer online buying behavior

Product Risk. Sometimes, online shopping websites fail to meet the consumer demand since it is difficult to judge their preferences on limited available information. Similarly, consumers can't trust the displayed product due to limited information. Most people do not buy online because they cannot examine the product physically, test the product, and lack product information (Kaur et al. 2015). In this way, Wai found a positive relation between product risk and consumer online shopping behavior (Wai et al. 2019). On the contrary, Bhatti used Confirmatory factor analysis (CFA) and structural equation modeling (SEM) techniques, and showed that product risk does not has a significant relation with online shopping (Bhatti et al. 2018)

H5: Product risk is negatively related to consumer online buying behavior

Inconvenience/security Risk. Safety issues and the availability of credit cards are the main barriers in online shopping (Bashir 2013). People in Pakistan are often reluctant to share their confidential information like credit card numbers, email addresses, and identity cards due to various internet scams that have caused financial damage to many people. This has made trust and confidence the main factors that affect the consumer buying behavior in Pakistan (Nazir et al. 2012). It has put a limit on the online shopping trend. The majority of people also lack credit cards due to financial illiteracy. Smith and Rupp (2003) identified that social, cultural, and psychological factors also affect the purchase and post-purchase decisions. The authors find that security and privacy are the main factors that affect online buying behavior.

H6: Security Risk is negatively related to consumer online buying behavior 


\section{Research Methodology}

The study is concerned with the investigation of the benefits and risks that consumers may encounter during online shopping. Seven variables i.e., shopping convenience, product selection, consumer buying behavior, ease, financial risk, product risk, security risk, are retrieved from literature to determine the consumer's perspective for benefits and risks. Consumer buying behavior is taken as a dependent variable that is being affected by six independent variables. A five-point Likert scale was used in which respondents could specify their level of agreement concerning the statement i.e.

(1) Strongly Disagree

(2) Disagree

(3) Neutral

(4) Agree

(5) Strongly Agree

The data is collected through Convenience sampling from students in academia, in Punjab province. Students are preferred in this study because they have been successfully used for primary research in many Web-related studies, [e.g. (Lee et al. 2005 ; Liu 2003)]. Before its distribution, the questionnaire was pretested to identify possible problems in terms of clarity and accuracy. Based on comments and feedback, several changes were made in order to improve the presentation of the items. The variables and questionnaire for the study are adapted from (Forsythe et al. 2006).

\section{Theoretical Framework}

The theoretical framework is given in Figure 2. Consumer buying behavior is taken as the dependent variable, which is being affected

by other variables.

Figure 2: Theoretical Framework

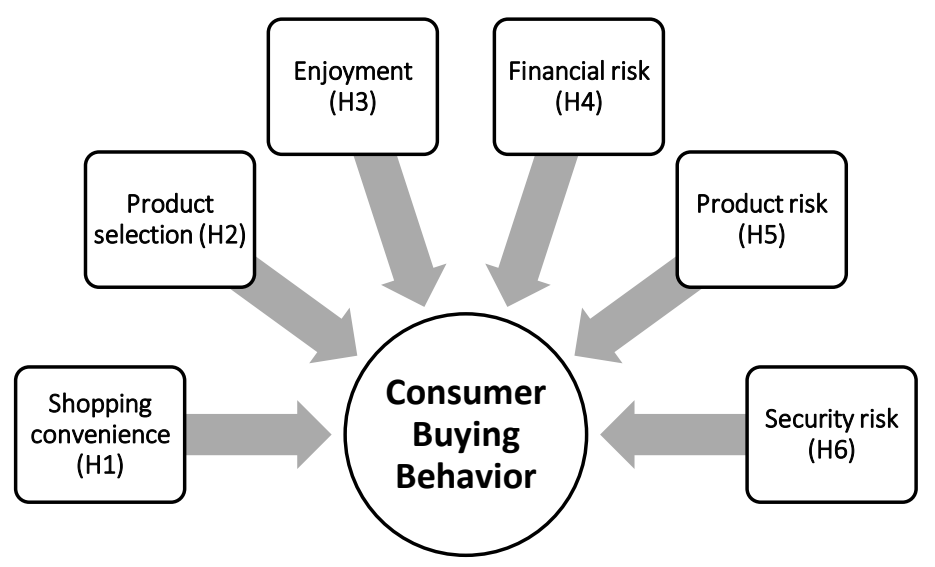

\section{Sampling Frame and Data Collection}

The data through questionnaires were collected from students belonging to a different gender, age, and education groups. Students were posed with close-ended questions. The questionnaire was uploaded on google forms, from where anyone with the link could open the form and give his/her response. 150 students returned the response with complete answers.

\section{Demographic profile.}


INTERNATIONAL JOURNAL OF ACADEMIC RESEARCH IN ACCOUNTING, FINANCE AND MANAGEMENT SCIENCES

Vol. 11, No. 1, 2021, E-ISSN: 2225-8329 @ 2021 HRMARS

Table 1provides the frequency and percentages for demographic characteristics of the respondents. There are 110 males (73.3\%) and 40 females (26.7\%) among the respondents. A total of 150 respondents recorded their responses. Among the respondents, the 18-23 age group is 127 in frequency which is about 84.7 in percentage measure, which is followed by 24-29 age group with 16 frequency and $10.7 \%$, and 30-35 age group with 5 frequency and 3.3\%. People of 36-40 age group are least in frequency i.e., 2 and percentage i.e., 1.3\%. Those respondents which are in bachelors' level of education are 118 (78.7\%), followed by Masters which are 19 (12.7), and Diploma holders are $12(8 \%)$. There is only $1(0.7 \%)$ Ph.D. holder.

Table 1: Demographic profile of respondents

\begin{tabular}{lll}
\hline Variable & Frequency & Percentage \\
\hline Gender & & \\
\hline Male & 110 & 73.3 \\
Female & 40 & 26.7 \\
Total & 150 & 100 \\
\hline Age & & \\
\hline $18-23$ & 127 & 84.7 \\
$24-29$ & 16 & 10.7 \\
$30-35$ & 5 & 3.3 \\
$36-40$ & 2 & 1.3 \\
Total & 150 & 100 \\
\hline Education & & \\
\hline Bachelors & 118 & 78.7 \\
Masters & 19 & 12.7 \\
PhD & 1 & 0.7 \\
Diploma/Any-other & 12 & 8 \\
Total & 150 & 100 \\
\hline
\end{tabular}

\section{Results}

To determine the statistical significance between independent variables, a chi-square test is performed using SPSS.

\section{Chi-Square Results}

\section{Gender*age cross-tabulation}

$\mathrm{HO}=$ Gender and age are independent variable

$\mathrm{H} 1=$ Gender and age are significantly associated

\begin{tabular}{l|l} 
& $\begin{array}{l}\text { Asymptotic } \\
\text { Significance } \\
\text { (2-sided) }\end{array}$ \\
\hline Pearson Chi-Square & .026 \\
\hline
\end{tabular}

Result $=\mathrm{p}<0.05$, which means $\mathrm{HO}$ is rejected and therefore gender and age are significantly associated. 
INTERNATIONAL JOURNAL OF ACADEMIC RESEARCH IN ACCOUNTING, FINANCE AND

\section{MANAGEMENT SCIENCES}

Vol. 11, No. 1, 2021, E-ISSN: 2225-8329 @ 2021 HRMARS

\section{Gender*education cross-tabulation}

$\mathrm{HO}=$ Gender and education are independent variable

$\mathrm{H} 1=$ Gender and education are significantly associated

\begin{tabular}{l|l} 
& $\begin{array}{l}\text { Asymptotic } \\
\text { Significance } \\
\text { (2-sided) }\end{array}$ \\
\hline Pearson Chi-Square & .066 \\
\hline
\end{tabular}

Result $=\mathrm{p}>0.05$, which means $\mathrm{H} 1$ is rejected, and therefore gender and education are independent. Age* education cross-tabulation

$\mathrm{HO}=$ Age and education are independent variable

$\mathrm{H} 1$ = Age and education are significantly associated

\begin{tabular}{l|l} 
& $\begin{array}{l}\text { Asymptotic } \\
\text { Significance } \\
\text { (2-sided) }\end{array}$ \\
\hline Pearson Chi-Square & .000 \\
\hline
\end{tabular}

Result $=\mathrm{p}<0.05$, which means $\mathrm{HO}$ is rejected and therefore age and education are significantly associated.

\section{Validity Statistics}

To check the validity of the questionnaire, the construct validity method is used. The results from the Pearson bivariate correlation show that all items have obtained a $p$-value greater than the Critical P-value at 0.01 significance level (

Table 2).

Table 2: Validity test

\begin{tabular}{lll}
\hline Constructs & Significance & $\mathrm{p}^{*}$ \\
\hline Shopping convenience & .000 & 0.714 \\
Product Selection & .000 & 0.719 \\
Ease & .000 & 0.735 \\
Consumer buying behavior & .000 & 0.717 \\
Financial Risk & .000 & 0.652 \\
Product Risk & .000 & 0.714 \\
Security risk & .000 & 0.635 \\
\hline
\end{tabular}

For $\mathrm{N}=150$

*Significance at 0.01 level (two-tailed)

For $\mathrm{N}=150$, the degree of freedom is 148 as $\mathrm{df}=\mathrm{N}-2$. The obtained $\mathrm{p}$-value for all constructs is greater than the critical value i.e., 0.208 , and is highly significant, so all of the items are valid and can be subjected to further analysis. 


\section{Cronbach's Alpha Test}

Cronbach's alpha test is used to assess the reliability of test items. The reliability test is applied to all seven sections of the variables. The results from the test (Table 3) show that all variables have reliability coefficients greater than 0.7 . So, according to the thumb rule, reliability of 0.70 or higher is acceptable.

Table 3: Reliability statistics

\begin{tabular}{lll}
\hline Variable & Items & Cronbach's Alpha \\
\hline Shopping convenience & 6 & 0.718 \\
Product selection & 6 & 0.812 \\
Ease/Comfort & 6 & 0.738 \\
Consumer buying behavior & 6 & 0.808 \\
Financial risk & 7 & 0.740 \\
Product risk & 6 & 0.833 \\
Security risk & 7 & 0.749 \\
Overall Reliability & $\mathbf{4 7}$ & $\mathbf{0 . 9 1 7}$ \\
\hline
\end{tabular}

\section{KMO and Bartlett's Test}

Table 2 provides the results of two tests i.e. KMO and Bartlett's test. To check the adequacy of data for factor analysis, a KMO test is performed. The findings show that the KMO value is greater than 0.5 , which means the sample is adequate.

Table 4: KMO \& Bartlett's test

\begin{tabular}{ll|l}
\hline Kaiser-Meyer-Olkin Measure of Sampling Adequacy. & .811 \\
\hline Bartlett's Test of Sphericity & Approx. Chi-Square & 3254.692 \\
\cline { 2 - 3 } & Df & 946 \\
\cline { 2 - 3 } & Sig. & .000 \\
\hline
\end{tabular}

a. Based on correlations

Bartlett test of sphericity is a statistical test used to verify the null hypothesis which states that variances are equal across groups or samples. This test is used to test if factor analysis may be useful with the data.

The null hypothesis for the test is that the variances are equal for all samples. In statistics terms, that's:

$$
\mathrm{H}_{0}: \quad \sigma_{1}{ }^{2}=\sigma_{2}{ }^{2}=\ldots=\quad \sigma_{\mathrm{k}}{ }^{2}
$$

The alternate hypothesis is that the variances are not equal for at least one pair or more:

$$
H_{1}: \sigma_{1}^{2} \neq \sigma_{2}^{2} \neq \ldots \neq \sigma_{k}^{2}
$$

The results of Bartlett's test show that the value of significance level is less than 0.05 , which means there is at least one significant correlation between two of the items. So, it rejects the null hypothesis, and a factor analysis would be useful with the data. 


\section{Hypothesis Testing}

H1: Shopping convenience is positively related to consumer online buying behavior

Since $p=0.000$ is less than the benchmark value of $0.05, \mathrm{H} 1$ is accepted. The positive Pearson correlation .521 between shopping convenience and consumer shopping behavior is moderate. The summary of Pearson correlation is given in Table 5.

Table 5: Correlation between Convenience and consumer buying behavior

\begin{tabular}{lll}
\hline Shopping Convenience & \multicolumn{2}{l}{ Consumer Shopping Behavior } \\
\cline { 2 - 3 } & Pearson Correlation & $.521^{* *}$ \\
& Sig. (2-tailed) & .000 \\
& $\mathrm{~N}$ & 150 \\
\hline
\end{tabular}

**Correlation is significant at the 0.01 level (2-tailed).

H2: Product selection is positively related to consumer online buying behavior

Since $p=0.000$ is less than the benchmark value of $0.05, \mathrm{H} 2$ is accepted. The positive Pearson correlation .544 between Product selection and consumer shopping behavior is moderate. The summary of Pearson correlation is given in

Table 6.

Table 6: Correlation between Product Selection and consumer buying behavior

\begin{tabular}{lll}
\hline Product Selection & \multicolumn{2}{l}{ Consumer Shopping Behavior } \\
\cline { 2 - 3 } & Pearson Correlation & $.544^{* *}$ \\
& Sig. (2-tailed) & .000 \\
$\mathrm{~N}$ & 150 \\
\hline
\end{tabular}

**Correlation is significant at the 0.01 level (2-tailed).

H3: Ease is positively related to consumer online buying behavior

Since $p=0.000$ is less than the benchmark value of $0.05, \mathrm{H} 3$ is accepted. The positive Pearson correlation .527 between Ease and consumer shopping behavior is moderate. The summary of Pearson correlation is given in

Table 7.

Table 7: Correlation between Ease and consumer buying behavior

\begin{tabular}{lll}
\hline Ease & \multicolumn{2}{l}{ Consumer Shopping Behavior } \\
\cline { 2 - 3 } & Pearson Correlation & $.527^{* *}$ \\
& Sig. (2-tailed) & .000 \\
$\mathrm{~N}$ & 150 \\
\hline
\end{tabular}

**Correlation is significant at the 0.01 level (2-tailed).

H4: Financial risk is negatively related to consumer online buying behavior

Since $p=0.001$ is less than the benchmark value of $0.05, \mathrm{H} 4$ is accepted. The positive Pearson correlation .262 between shopping convenience and consumer shopping behavior is not significant. The summary of Pearson correlation is given in Table 8. 
Table 8: Correlation between Financial Risk and consumer buying behavior

\begin{tabular}{lll}
\hline Financial Risk & \multicolumn{2}{l}{ Consumer Shopping Behavior } \\
\cline { 2 - 3 } & Pearson Correlation & $.262^{* *}$ \\
& Sig. (2-tailed) & .001 \\
$\mathrm{~N}$ & 150
\end{tabular}

**Correlation is significant at the 0.01 level (2-tailed).

H5: Product risk is negatively related to consumer online buying behavior

Since $p=0.000$ is less than the benchmark value of $0.05, \mathrm{H} 5$ is accepted. The positive Pearson correlation .331 between Product Risk and consumer shopping behavior is not significant. The summary of Pearson correlation is given in Table 9.

Table 9: Correlation between Product Risk and consumer buying behavior

\begin{tabular}{lll}
\hline Product Risk & \multicolumn{2}{l}{ Consumer Shopping Behavior } \\
\cline { 2 - 3 } & Pearson Correlation & $.331^{* *}$ \\
& Sig. (2-tailed) & .000 \\
$\mathrm{~N}$ & 150
\end{tabular}

**Correlation is significant at the 0.01 level (2-tailed).

H6: Security Risk is negatively related to consumer online buying behavior

Since $p=0.000$, which is less than the benchmark value of $0.05, \mathrm{H} 6$ is accepted. The positive Pearson correlation .346 between security and consumer shopping behavior is not significant. The summary of Pearson correlation is given in Table 10.

Table 10: Correlation between Enjoyment and consumer buying behavior

\begin{tabular}{lll}
\hline Enjoyment & \multicolumn{2}{l}{ Consumer Shopping Behavior } \\
\cline { 2 - 3 } & Pearson Correlation & $.346^{* *}$ \\
& Sig. (2-tailed) & .000 \\
$\mathrm{~N}$ & 150 \\
\hline
\end{tabular}

**Correlation is significant at the 0.01 level (2-tailed).

So, all the hypothesis are accepted, and Table 11 gives a brief summary of all the results.

Table 11: Summary of Results

\begin{tabular}{ll}
\hline Hypothesis & Result \\
\hline H1 & Accepted \\
H2 & Accepted \\
H3 & Accepted \\
H4 & Accepted \\
H5 & Accepted \\
H6 & Accepted \\
\hline
\end{tabular}


INTERNATIONAL JOURNAL OF ACADEMIC RESEARCH IN ACCOUNTING, FINANCE AND

MANAGEMENT SCIENCES

Vol. 11, No. 1, 2021, E-ISSN: 2225-8329 @ 2021 HRMARS

\section{Conclusion and Recommendations}

This study provides empirical support to the benefits and risks that affect the consumers' online buying behavior. It is found that shopping convenience, product selection, and ease of buying give a positive incentive to consumers to shop online. On the other hand, product risk, financial risk are the major hindrances in the way of online buyers. It is concluded that consumers perceive certain benefits and risks in online shopping, which affects their choice of whether to shop online or in-person. Based on the findings, it is recommended that to enhance customer purchase intentions, online stores should work on developing marketing strategies to address the trustworthiness, reliability, and quality of the products. Online stores can devote valuable corporate resources to the important eservice quality attributes identified by this study.

\section{References}

Akhter, S. H. (2015). Impact of internet usage comfort and internet technical comfort on online shopping and online banking. Journal of International Consumer Marketing, 27(3), 207-219.

Almarashdeh, I., Jaradat, G., Abuhamdah, A., Alsmadi, M., Alazzam, M. B., Alkhasawneh, R., \& Awawdeh, I. (2019). The difference between shopping online using mobile apps and website shopping: A case study of service convenience. International Journal of Computer Information Systems Industrial Management Applications, 11, 151-160.

Bashir, A. (2013). Consumer Behavior towards online shopping of electronics in Pakistan.

Beauchamp, M. B., \& Ponder, N. J. T. M. M. J. (2010). Perceptions of retail convenience for in-store and online shoppers. 20(1), 49-65.

Bhatti, A., Saad, S., \& Gbadebo, S. M. (2018). Convenience risk, product risk, and perceived risk influence on online shopping: Moderating effect of attitude. Science Arena Publications International journal of Business Management, 3(2), 1-11.

Bin Dost, M. K., Illyas, M., \& Abdul Rehman, C. (2015). Online shopping trends and its effects on consumer buying behavior: A case study of young generation of Pakistan. NG-Journal of Social Development, 417(3868), 1-22.

Cheema, U., Rizwan, M., Jalal, R., Durrani, F., \& Sohail, N. (2013). The trend of online shopping in 21st century: Impact of enjoyment in TAM Model. Asian Journal of Empirical Research, 3(2), 131141.

Delhagen, K. (1997). Retails Revs Up. Forester Research, 4(6).

Forsythe, S., Liu, C., Shannon, D., \& Gardner, L. C. (2006). Development of a scale to measure the perceived benefits and risks of online shopping. Journal of interactive marketing, 20(2), 5575.

Guo, X., Ling, K. C., \& Liu, M. (2012). Evaluating factors influencing consumer satisfaction towards online shopping in China. Asian Social Science, 8(13), 40.

Hussain, M. A., Anwar, M. Z., Mehboob, H., Majeed, A., \& Samin, T. (2011). Virtual Shopping and Impulse Purchasing Strengths and Weaknesses in Pakistan. IJCSI.

Jih, W.-J. (2007). Effects of consumer-perceived convenience on shopping intention in mobile commerce: an empirical study. International Journal of E-Business Research, 3(4), 33-48.

Kaur, G., \& Quareshi, T. K. (2015). Factors obstructing intentions to trust and purchase products online. Asia Pacific Journal of Marketing Logistics.

Khatibi, A., Haque, A., \& Karim, K. (2006). E-Commerce: A study on internet shopping in Malaysia. Journal of Applied Sciences, 6(3), 696-705. 
INTERNATIONAL JOURNAL OF ACADEMIC RESEARCH IN ACCOUNTING, FINANCE AND

MANAGEMENT SCIENCES

Vol. 11, No. 1, 2021, E-ISSN: 2225-8329 @ 2021 HRMARS

Koyuncu, C., \& Bhattacharya, G. (2004). The impacts of quickness, price, payment risk, and delivery issues on on-line shopping. The Journal of Socio-Economics, 33(2), 241-251.

Kuhlmeier, D., \& Knight, G. (2005). Antecedents to internet-based purchasing: a multinational study. International Marketing Review.

Lee, G. G., Lin, H. F., \& Management, D. (2005). Customer perceptions of e-service quality in online shopping. International Journal of Retail.

Liu, Y. (2003). Developing a scale to measure the interactivity of websites. Journal of advertising research, 43(2), 207-216.

Masoud, E. Y. (2013). The effect of perceived risk on online shopping in Jordan. European Journal of Business Management, 5(6), 76-87.

Monsuwé, T. P., Dellaert, B. G., \& De Ruyter, K. (2004). What drives consumers to shop online? A literature review. International journal of service industry management.

Nazir, S., Tayyab, A., Sajid, A., Ur Rashid, H., \& Javed, I. (2012). How online shopping is affecting consumers buying behavior in Pakistan? International Journal of Computer Science Issues, 9(3), 486.

Pi, S.-M., \& Sangruang, J. (2011). The perceived risks of online shopping in Taiwan. Social Behavior Personality: an international journal, 39(2), 275-286.

Ramayah, T., \& Ignatius, J. (2005). Impact of perceived usefulness, perceived ease of use and perceived enjoyment on intention to shop online. ICFAl Journal of Systems Management, 3(3), 36-51.

Smith, A. D., \& Rupp, W. T. (2003). Strategic online customer decision making: leveraging the transformational power of the Internet. Online information review.

Tauber, E. M. (1995). Why do people shop? Marketing Management, 4(2), 58.

Wai, K., Dastane, O., Johari, Z., \& Ismail, N. B. (2019). Perceived risk factors affecting consumers' online shopping behaviour. The Journal of Asian Finance, Economics Business, 6(4), 246-260. 